\title{
Betalain pigments as natural photosensitizers for dye-sensitized solar cells: the effect of dye pH on the photoelectric parameters
}

\author{
Kasim Uthman Isah • Umar Ahmadu • Adamu Idris • \\ Mohammed Isah Kimpa • Uno Essang Uno • Muhammed Muhammed Ndamitso • \\ Noble Alu
}

Received: 28 July 2014/Accepted: 23 October 2014/Published online: 7 November 2014

(C) The Author(s) 2014. This article is published with open access at Springerlink.com

\begin{abstract}
Dye-sensitized solar cells (DSSC) were fabricated using red bougainvillea glabra flower dye extracts as natural dye sensitizers at three dye $\mathrm{pH}$ values of $1.23,3.0$, and 5.7. Water was used as dye-extracting solvent. DSSCs from dye extract of $\mathrm{pH} 3.0$ had the highest photocurrent density $J_{\mathrm{sc}}$ of $3.72 \mathrm{~mA} / \mathrm{cm}^{2}$ and fill factor FF of 0.59 . While the DSSCs from dye sensitizer pHs of 1.23 and 5.7 had $J_{\mathrm{sc}}$ of 1.13 and $2.27 \mathrm{~mA} / \mathrm{cm}^{2}$, and fill factors of 0.43 and 0.61 , respectively. The maximum powers $P_{\max }$ of the DSSCs were $0.50,1.64$, and $0.94 \mathrm{~mW} / \mathrm{cm}^{2}$ for dye sensitizer $\mathrm{pH}$ of 1.2, 3.0, and 5.7, respectively.
\end{abstract}

Keywords Dye-sensitized solar cell - Dye sensitizer . Bougainvillea glabra $\cdot \mathrm{PH}$

\section{Introduction}

Dye-sensitized solar cell (DSSC) developed by Gratzel et al. [1] has attracted considerable attention due to its environmental friendliness and relative low cost of production [2]. Sensitizer dye in DSSC plays a key role in harvesting sunlight and transforming solar energy into

K. U. Isah (凹) · U. Ahmadu · A. Idris ·

M. I. Kimpa - U. E. Uno

Department of Physics, Federal University of Technology,

Minna, Nigeria

e-mail: kasim309@futminna.edu.ng

M. M. Ndamitso

Department of Chemistry, Federal University of Technology,

Minna, Nigeria

N. Alu

Physics Advanced Laboratory, Sheda Science and Technology complex Sheda, Abuja, Nigeria electric energy and thus of paramount importance to photovoltaic cell performance and efficiency [3]. It attaches to the surface of a wide band-gap mesoporous semiconductor serving as electron transporter [4]. Ruthenium-based dye sensitizers are very expensive and hard to prepare, which restricts their large-scale applications in solar cells, stimulating the search for alternatives such as natural dyes.

Anthocyanins from natural pigments and carotenoids have been used as natural dye sensitizers in DSSC and have shown low to modest solar energy conversion efficiencies $[2,5-7]$. These natural dyes are easy to prepare, cheap, non-toxic, environmentally friendly, and easily biodegradable.

Betalain is another interesting class of pigments, whose purified extracts from commercial sources have been subjected to photoelectrochemical study [8]. Betalains consisting of the yellow betaxanthins and red-violet betacyanins are a group of water-soluble nitrogen-containing alkaloid pigments characteristic of certain members of plant sub-order chenopodineae within caryophyllales and some higher fungi [9]. They absorb visible radiation over the range $476-600 \mathrm{~nm}$, they are immonium derivatives of betalamic acid (the chromophore of all betalains) and divided into two structural groups: the red-violet betacyanins that have a maximum absorptivity at $\lambda \approx 535 \mathrm{~nm}$ and the yellow-orange betaxanthins with maximum absorptivity at $\lambda \approx 480 \mathrm{~nm}$ [10-13]. Betalains are characterized by high molar extinction coefficients in the visible region and $\mathrm{pH}$-dependent redox properties [14, 15]. They are relatively stable over $\mathrm{pH}$ range $3-7$, however, at $\mathrm{pH}$ less than 3.5 the absorption maximum shifts toward lower wavelength [16]. Acidic conditions are known to induce recondensation of betalamic acid with amine group of the addition residue [17] and favors betalain-sensitized photo-electrodes with high optical densities capable of 


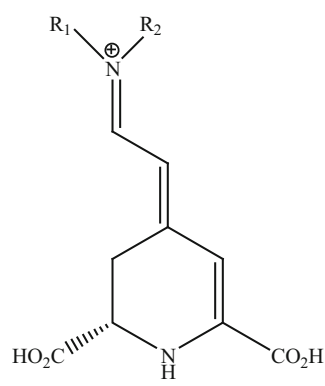

(a)

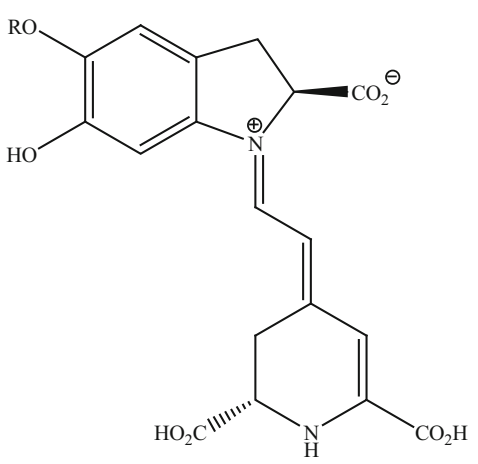

(b)
Fig. 1 General structures of the main betalain a betaxanthin $\left(\mathrm{R}_{1}=H\right.$ and $\mathrm{R}_{2}=$ amine or amino acid group), b betacyanin ( $R=\beta$-D-glucose)

complete absorption in the visible range of $400-600 \mathrm{~nm}$ [6]. Solar energy conversion efficiency being a function of photocurrent density $J_{\mathrm{sc}}$, open-circuit voltage $V_{\mathrm{oc}}$, and fill factor FF [18], suggest their improvement is essential to raising conversion efficiency.

This work reports the use of water extracts of red Bougainvillea glabra flower a source of betalain as natural dye sensitizer and the influence of sensitizer dye $\mathrm{pH}$ on the photoelectric parameters of the DSSCs.

Bougainvillea is a member of the Nyctaginaceae family comprising of 18 shrubby species which though indigenous of South America are distributed widely in the world, with flowers ranging from white, yellow, orange, and various shades of red to purple and violet color [12-14]. The Betalain pigment in Bougainvillea is different from that in other sources due to the presence of saccharide type present in the betanidin (an aglycone of most betacyanins) which is produced $90 \%$ from betacyanins, and the remaining $10 \%$ comes from indicaxanthin a common betaxanthin [15]. Bougainvillea glabra has been found to have eleven violetred pigments having maximum absorbance in wavelength range of 522-551 nm and is known to have two epimeric betacyanins; bougainvillein-r-1 and isobougainvillein-r-1 [15].

The general structure of Betalain is shown in Fig. 1 [10]; it contains carboxylic functional group which facilitates $\mathrm{TiO}_{2}$ surface binding.

\section{Experimental}

The red Bougainvillea glabra flower dye pigments were extracted by crushing $20 \mathrm{~g}$ of the flower in a porcelain mortar with a pestle and adding $50 \mathrm{ml}$ of water to the crushed sample. This was filtered to get the raw dye extracts of the flower which was divided into three and used as sensitizing dye at three different $\mathrm{pHs}$. The first, the as-extracted dye had a $\mathrm{pH}$ of 5.70 , the $\mathrm{pH}$ of the second was adjusted to 3.0 by adding 4 drops of $20 \% \mathrm{HCl}$ to it, and the third after adding 8 drop of $\mathrm{HCl}$ had a $\mathrm{pH}$ value 1.23.

The transparent conducting oxide was fluorine-doped tin oxide (FTO) with a sheet resistance of $15 \Omega / \mathrm{cm}^{2}$ (SOLARONIX). The $\mathrm{TiO}_{2}$ film was prepared by blending commercial $\mathrm{TiO}_{2}$ powder (Degussa, P25) of Ca. $0.2 \mathrm{~g}$, nitric solution $(0.1 \mathrm{M})$ of $0.4 \mathrm{ml}$, polyethylene glycol (MW 10,0000 ) of ca. $0.08 \mathrm{~g}$, and one drop of a non-ionic surfactant, Triton $\mathrm{x}-100$. The mixture was well blended using an ultrasonic bath for $1 \mathrm{~h}$. Squeegee was used to screenprint the resulting $\mathrm{TiO}_{2}$ paste on the conducting layer/FTO glass substrate. It was left for $30 \mathrm{~min}$ so that the paste could settle to reduce the irregularity of the surface. The substrates were then left to dry. This screen-printing procedure was repeated to obtain the $\mathrm{TiO}_{2}$ working electrode of appropriate thickness of $9 \mu \mathrm{m}$.

Prior to sensitisation, the $\mathrm{TiO}_{2}$ photo-anodes were preheated at $150{ }^{\circ} \mathrm{C}$ for $30 \mathrm{~min}$, allowed to cool. It was then subjected to $\mathrm{TiCl}_{4}$ treatment by immersing in $40 \mathrm{mM}$ of $\mathrm{TiCl}_{4}$ solution for $30 \mathrm{~min}$ at a temperature of $70{ }^{\circ} \mathrm{C}$ and subsequently sintered at $450{ }^{\circ} \mathrm{C}$ for $45 \mathrm{~min}$. After cooling to $80{ }^{\circ} \mathrm{C}$, the $\mathrm{TiO}_{2}$ electrodes were immersed into the three dye solutions of $\mathrm{pH} 1.23,3.0$, and 5.7 for $16 \mathrm{~h}$. The photoelectrode were then rinsed with $99 \%$ ethanol solution, to remove excess dye and thereafter left to dry. The counter electrode was made from platinum catalyst T/SP product by SOLARONIX which was screen-printed using a polyester mesh of 90 and dried. The substrates were sintered for $1 \mathrm{~h}$ at $45{ }^{\circ} \mathrm{C}$. The DSSC was assembled from the various components following the procedure reported elsewhere [19].

\section{Characterization}

The absorption spectra of the dyes were determined using an AVASPEC 2048 UV-Visible spectrophotometer, while the morphology and composition characterization of the nanoporous $\mathrm{TiO}_{2}$ film was carried out using Carl Zeiss EVO MA-10 scanning electron microscope (SEM), with EDX model ISIS 300 Oxford. Simulated Solar irradiation was provided by a Solar Simulator, Model 4200-SCS Semiconductor Characterization System under the irradiation of AM $1.5\left(100 \mathrm{mWcm}^{-2}\right)$, and the Current-Voltage curves were recorded by a digital Keithley multimeter Model 2400 coupled to a computer.

\section{Results and discussion}

Figure 2 shows the UV-Vis optical absorption spectra of the bougainvillea flower dye extracts at three different $\mathrm{pHs}$. 


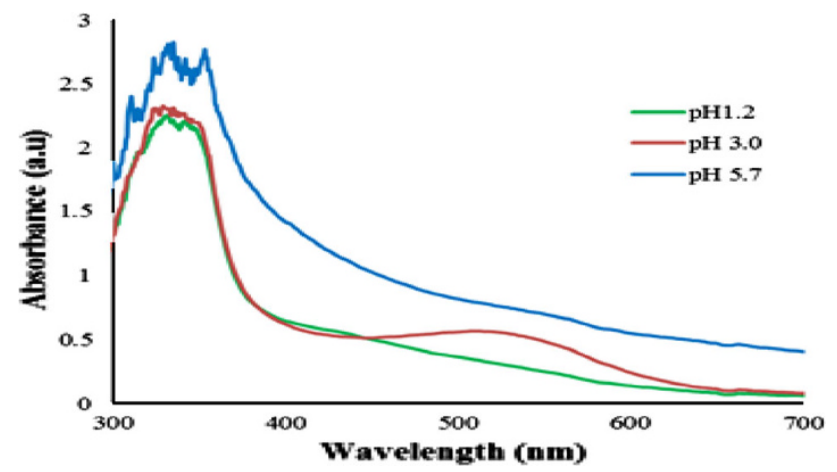

Fig. 2 Absorption spectrum of the dye extract from red bougainvillea glabra flower for $\mathrm{pH}_{1.2}, \mathrm{pH}_{3.0}$, and $\mathrm{pH}_{5.7}$

Absorption spectra of a dye reflect optical transition probability between the ground state, the excited state and the solar energy range absorbed by the dye. The three dyes' extracts show absorption peaks centered between 310 and $340 \mathrm{~nm}$ in the UV-range, with maximum peaks at $330 \mathrm{~nm}$ for $\mathrm{pH} 5.7$ and $327 \mathrm{~nm}$ for $\mathrm{pH} 3.0$ and 1.2. The dye extracts at $\mathrm{pH} 1.23$ and 3.0 have about the same absorption intensity in short wavelength range, with dye extract at a $\mathrm{pH}$ of 5.7 having the highest intensity in this range. The lowest absorption intensity in the long wavelength is observed for dye $\mathrm{pH}$ of 1.2 , indicating a highly suppressed absorbance as a result of degradation of betanin in very strong acidic environment [20]. Dye extract at a $\mathrm{pH}$ of 3 displays broad absorption peak in the $480-560 \mathrm{~nm}$ range resulting from $\pi-\pi^{*}$ transitions due to the mixed contributions of the yellow-orange betaxanthins $(480 \mathrm{~nm})$ and of the red-purple betacyanin $(540 \mathrm{~nm})$ [6]. At a pH of 5.7, the extract has a highest but flattened absorption spectrum in the longrange wavelength indicating a suppressed absorption peak at this $\mathrm{pH}$ and a wider range of red, orange, yellow, and blue light can be absorbed. Absorbance peaks around 300 and $535 \mathrm{~nm}$ are characteristic absorptions for red-violet betalain group, betacyanin [14].

The betaxanthin and betanin concentration in the dye extracts in $\mu \mathrm{M}$ are estimated from the absorbance $\mathrm{A}$ at 482 and $536 \mathrm{~nm}$ from the absorbance spectra using [10],

$$
\begin{aligned}
{\left[\mathrm{B}_{\text {betax }}\right] } & =23.8 \mathrm{~A}_{482}-7.7 \mathrm{~A}_{536} \\
{\left[\mathrm{~B}_{\text {betan }}\right] } & =15.38 \mathrm{~A}_{536}
\end{aligned}
$$

$\left[\mathrm{B}_{\text {betax }}\right]$ is the betaxanthin concentration and $\left[\mathrm{B}_{\text {betan }}\right]$ the betanin concentration. The betaxanthin concentrations were $7.39,8.79$, and $15.17 \mu \mathrm{M}$ for $\mathrm{pH}$ of $1.23,3.0$, and 5.7 , respectively, while the betanin concentration at a $\mathrm{pH}$ of $1.2, \quad 3.0$ and 5.7 were $4.35,8.15$, and $11.26 \mu \mathrm{M}$, respectively.

Figure 3 shows the scanning electron micrograph of the $\mathrm{TiO}_{2}$ (anatase) film. The $\mathrm{TiO}_{2}$ film has thickness of $9 \mu \mathrm{m}$ and a mean particle size of $20 \mathrm{~nm}$. It shows a mesoporous

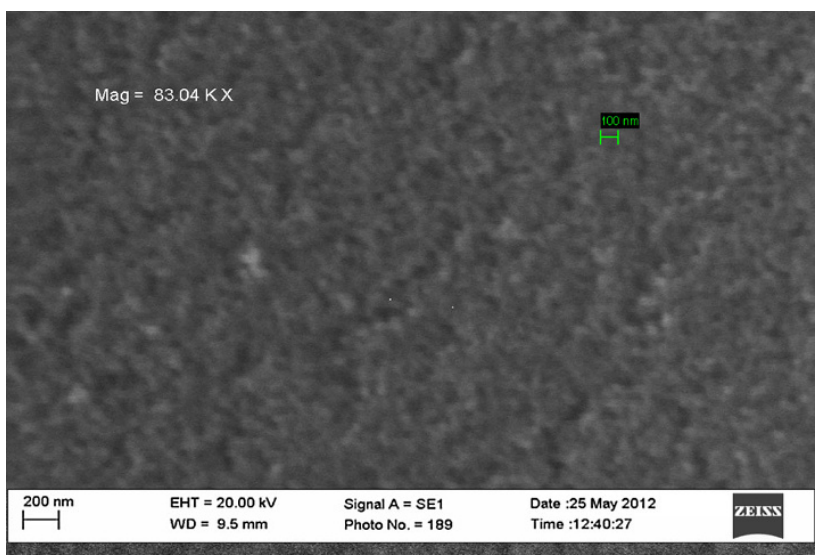

Fig. 3 SEM micrograph of a nanoporous $\mathrm{TiO}_{2}$ (anatase) film

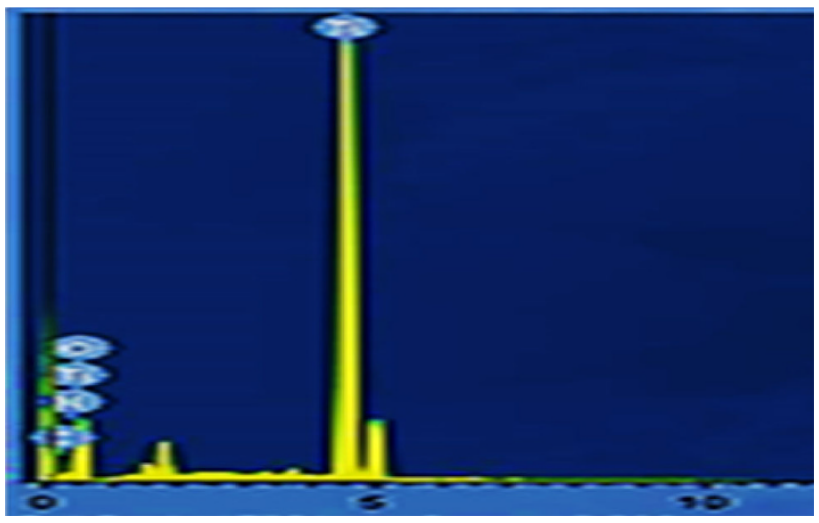

Fig. 4 Elemental composition of $\mathrm{TiO}_{2}$ compound

surface of the spherical nanoparticles of $\mathrm{TiO}_{2}$ that forms nanopores across the surface. The EDX analysis of the $\mathrm{TiO}_{2}$ electrode in Fig. 4 shows the presence of Titanium, Oxygen, Nitrogen, and Carbon. The presence of chlorine in the compound was due to $\mathrm{TiCl}_{4}$ which was applied at a final treatment of the porous $\mathrm{TiO}_{2}$ electrodes in the anatase $\mathrm{TiO}_{2}$ compound contained.

The current-voltage curve of a solar cell yields important photoelectric parameters such as short-circuit current density $J_{\mathrm{sc}}$, the open-circuit voltage $V_{\mathrm{oc}}$, the current $I_{\mathrm{mp}}$, and voltage $V_{\mathrm{mp}}$ at the maximum power point $P_{\max }$. The photoelectric characteristics of the DSSCs were inspected under the simulated sunlight source (AM1.5).

The combined $\mathrm{J}-\mathrm{V}$ and $\mathrm{P}-\mathrm{V}$ curves of the DSSCs at different $\mathrm{pHs}$ are shown in Fig. 5. The open-circuit voltage $V_{\mathrm{oc}}$ of $0.44 \mathrm{~V}$ is obtained for dye $\mathrm{pH}$ of 1.2 and 3.0, respectively, while at a $\mathrm{pH}$ of 5.7 the $V_{\mathrm{oc}}$ is 0.41 . The DSSC prepared from a dye $\mathrm{pH}$ of 3.0 has the highest photocurrent density $J_{\mathrm{sc}}$ of $3.72 \mathrm{~mA} / \mathrm{cm}^{2}$ and fill factor of and 0.59. At a dye sensitizer $\mathrm{pH}$ of 1.2, the DSSC has the lowest Photocurrent density of $1.13 \mathrm{~mA} / \mathrm{cm}^{2}$ and lowest fill factor of 0.43 due to betanin degradation in very strong 


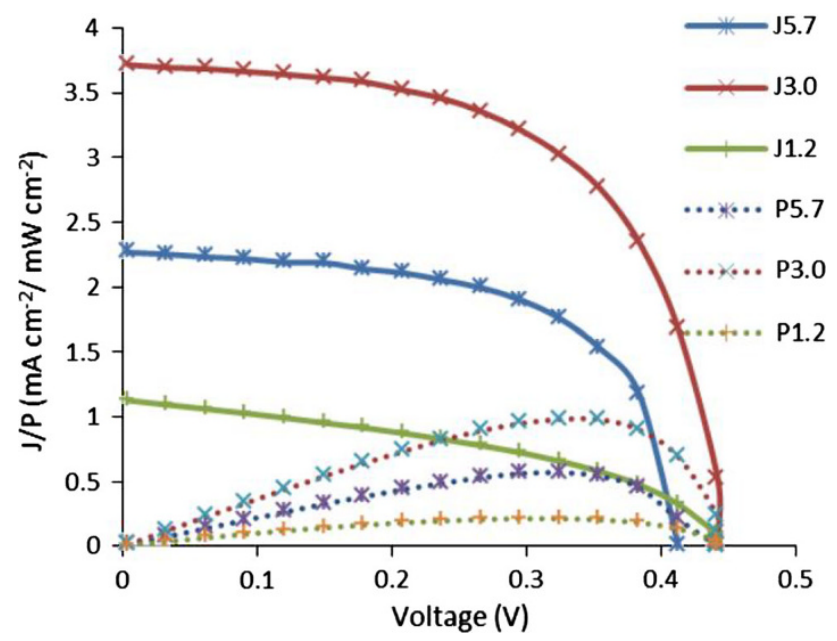

Fig. 5 Combine J-V and P-V curves of the cells for dye sensitizers at $\mathrm{pH}$ of $1.2,3.0$, and 5.7

Table 1 Photoelectric parameters of the cells sensitized with natural extracts

\begin{tabular}{llllll}
\hline Dye $\mathrm{pH}$ & $J_{\mathrm{sc}}\left(\mathrm{mA} / \mathrm{cm}^{2}\right)$ & $V_{\mathrm{oc}}(\mathrm{V})$ & $P_{\max }\left(\mathrm{mW} / \mathrm{cm}^{2}\right)$ & FF & $\eta$ \\
\hline 1.2 & 1.13 & 0.44 & 0.50 & 0.43 & 0.21 \\
3.0 & 3.72 & 0.44 & 1.64 & 0.59 & 0.98 \\
5.7 & 2.27 & 0.412 & 0.94 & 0.61 & 0.57 \\
\hline
\end{tabular}

acidic environment $[17,20]$ with resultant inefficient light harvesting by the dye and inefficient charge injection into the $\mathrm{TiO}_{2}$ nanoparticles; also possible cell deterioration by acid leaching is expected as the $\mathrm{pH}$ goes lower.

The reduction in photoelectrical property observed at $\mathrm{pH}$ 5.7 compared to $\mathrm{pH} 3$ results because at high $\mathrm{pH}$ betanin is poorly absorbed onto titania due to its inhibition by indicaxanthin (a common betaxanthin in red bougainvillea) competing with betanin for adsorption sites, but at lower $\mathrm{pH}$ protonation of the betalainic carboxylic acid group from its anionic form occurs promoting its adsorption onto the $\mathrm{TiO}_{2}$ [14].

The photoelectric parameters are listed in Table 1.

The obtained photoelectric parameters using bougainvilla glabra flower dye extract as sensitizer dye at $\mathrm{pHs}$ of $1.2,3.0$, and 5.7 are comparable to $J_{\mathrm{sc}}$ of 1.881-2.344 mA/ $\mathrm{cm}^{2}$ though with lower $V_{\text {oc }}$ of $0.23-0.26 \mathrm{~V}$ from betalain pigments extracted from bracts of bougainvilla glabra and bougainvilla spectabilis at a $\mathrm{pH}$ of 5.7 [14].

Also although $J_{\mathrm{sc}}$ of up to $9.5 \mathrm{~mA} / \mathrm{cm}^{2}$ have been reported at a dye $\mathrm{pH}$ of 1.0 from other sources of betalain, corresponding $V_{\mathrm{oc}}$ was just between $0.23-0.3 \mathrm{~V}$ [6]. The obtained photoelectric parameters at dye pHs of 1.23 and 5.7 are much lower than that of black dye. The black dye has a certified $J_{\mathrm{sc}}$ of $20.5 \mathrm{~mA} / \mathrm{cm}^{2}$ and a $V_{\mathrm{oc}}$ of $0.72 \mathrm{~V}$ and is superior to all charge-transfer sensitizers on the basis of photovoltaic performance under AM 1.5 [21]. The $J_{\mathrm{sc}}$ $3.72 \mathrm{~mA} / \mathrm{cm}^{2}$ at dye sensitizer $\mathrm{pH}$ of 3.0 is encouraging.

\section{Conclusion}

Betalain raw extracts of red bougainvillea glabra flower were used as natural dye sensitizers for DSSCs at different dye sensitizer $\mathrm{pH}$ values. At a $\mathrm{pH}$ of 1.23 , the DSSC had the lowest parameters as a result of betalain degradation in very acidic environment and leaching of the dye from the $\mathrm{TiO}_{2}$ surface. The DSSC from dye sensitizer $\mathrm{pH}$ of 3.0 offered the highest $J_{\mathrm{sc}}$ of $3.72 \mathrm{~mA} / \mathrm{cm}^{2}$, a FF of 0.59 , and highest $P_{\max }$ of $1.64 \mathrm{~mW} / \mathrm{cm}^{2}$. The poor absorption of betanin onto the titania at high $\mathrm{pH}$ lead to decreased photoelectrical parameter of the cell at $\mathrm{pH}$ of 5.7. The obtained photoelectric parameters are much lower than that of black dye which is superior to all charge-transfer sensitizers on the basis of photovoltaic performance under AM 1.5 presently, with a certified $J_{\text {sc }}$ of $20.5 \mathrm{~mA} / \mathrm{cm}^{2}$ and a $V_{\text {oc }}$ of $0.72 \mathrm{~V}$ [21]. Nevertheless, natural bougainvillea glabra flower betalain raw extracts present promising low-cost, non-toxic, and environmentally friendly alternative photosensitizers in DSSCs.

Acknowledgments This study was supported by grant from the University Board of Research (UBR) of the Federal University of Technology, Minna, Nigeria.

Open Access This article is distributed under the terms of the Creative Commons Attribution License which permits any use, distribution, and reproduction in any medium, provided the original author(s) and the source are credited.

\section{References}

1. O'Regan, B., Grätzel, M.: A low cost high-efficiency solar cell based on dye-sensitized colloidal $\mathrm{TiO}_{2}$ films. Nature 353, 737-740 (1991)

2. Zhou, H., Wu, L., Gao, Y., Ma, T.: Dye-sensitized solar cells using 20 natural dyes as sensitizers. J. Photochem. Photobiol. A Chem 219, 188-194 (2011)

3. Chang, H., Wu, H.M., Chen, T.L., Huang, K.D., Jwo, C.S., Lo, Y.J.: Dye-sensitized solar cell using natural dyes extracted from spinach and ipomoea. J. Alloys Compd. 495(2), 606-610 (2010)

4. Erten-Ela, S.: Photovoltaic effect of nanostructured $\mathrm{TiO}_{2}$ layers in dye sensitized solar cells. J. Optoelectron. Adv. Mater. 14(9-10), 758-762 (2012)

5. Dai, Q., Rabani, J.: Photosensitization of nanocrystalline $\mathrm{TiO}_{2}$ films by anthocyanin dyes. J. Photochem. Photobiol. A Chem. 148, 17-24 (2002)

6. Calogero, G., Di Marco, G., Cazzanti, S., Caramori, S., Argazzi, R., Di Carlo, A., Alberto Bignozzi, C.: Efficient dye-sensitized solar cells using red turnip and purple wild Sicilian prickly pear fruits. Inter. J. Mol. Sci. 11, 254-267 (2010)

7. Gao, F.G., Bard, A.J., Kispert, L.D.: Photocurrent generated on a carotenoid-sensitized $\mathrm{TiO}_{2}$ nanocrystalline mesoporous electrode. J. Photochem. Photobiol. A Chem. 130, 49-56 (2000) 
8. Zhang, D., Lanier, S.M., Downing, J.A., Avent, J.L., Lum, J., McHale, J.L.: Betalain, pigments for dye-sensitized solar cells. J. Photochem. Photobiol. A Chem. 195, 72-80 (2008)

9. Koboyashi, N., Schmidt, J., Wray, V., Schliemann, W.: Formation and occurrence of dopamine-derived betacyanins. Phytochem. 56, 429-436 (2001)

10. Strack, D., Vogt, T., Schliemann, W.: Recent advances in betalain research. Phytochem. 62, 247-269 (2003)

11. Azeredo, H.M.C.: Betalains, properties, sources, applications, and stability-a review. Inter. J. Food Sci. Technol. 44, 2365-2376 (2009)

12. Mabberley, D.F.: A Portable Dictionary of Vascular Plants. Cambridge University Press, UK (1997)

13. Impellizzeri, G., Piattelli, M., Sciuto, S.: Acylated betacyanins from Drosanthemum floribundum. Phytochem. 12, 2295-2296 (1973)

14. Hernández-Martínez, A. R.,, Vargas S., Estevez, M., Rodríguez, R.: Dye-sensitized solar cells from extracted bracts Bougainvillea betalain pigments. In: 1st International Congress on Instrumentation and Applied Sciences, Cancun, Q. R., Mexico, 26-29 Oct 2010
15. Piattelli, M., Imperato, F.: Pigments of Bougainvillea glabra. Phytochem. 9, 2557-2560 (1970)

16. Jackman, R.L., Smith, J.L.: Anthocyanins and betalains. In: Hendry, G.F., Houghton, J.D. (eds.) Natural Food Colourants, pp. 244-309. Blackie Academic \& Professional, London (1996)

17. Schwartz, S.J., von Elbe, J.H.: Identification of betanin degradation products. Eur. Food Res. Technol. 176, 448-453 (1983)

18. Sze, S.M., Lee, M.: Physics of Semiconductor Devices. Wiley, New York (1969)

19. Kimpa, M.I., Momoh, M., Isah, K.U., Yahya, H.N., Ndamitso, M.M.: Photoelectric characterization of dye sensitized solar cells using natural dye from pawpaw leaf and flame tree flower as sensitizers. Mater. Sci. Appl. 3, 281-286 (2012)

20. Pedreno, M.A., Escribano, J.: Correlation between antiradical activity and stability of betanine from Beta vulgaris L roots under different $\mathrm{pH}$, temperature and light conditions. J. Sci. Food Agric. 81, 627-631 (2001)

21. Qin, Y., Peng, Q.: Ruthenium sensitizers and their applications in dye-sensitized solar cells. Inter. J. Photoenerg. 2012, 1-21 (2012) 